\title{
Challenges of Information Infrastructures for Open Science and Academic Libraries
}

\author{
Jela Steinerová \\ ORCID: 0000-0002-6360-0519 \\ Department of Library and Information Science, \\ Faculty of Arts, Comenius University in Bratislava, Slovakia
}

\begin{abstract}
Purpose/Thesis: The paper reviews the main concepts of information infrastructure, information environment, and information behavior of researchers in the context of digital revolution. The concept of open science and new models of scholarly communication are considered.

Approach/Methods: Related studies of information infrastructure and information behavior of researchers are analyzed. We report on the results of a series of qualitative studies of information behavior and of information ecology of the academic environment in Slovakia based on interviews with doctoral students, expert researchers and information managers. We apply a previously developed original methodology of concept mapping.

Results and conclusions: The results allow us to re-consider relevance assessment in the digital environment and to present a model of the information ecology in the information environment. We present the analyzed data represented by the concept maps which show the attitudes of researchers to open science, economic models of science and values of researchers. The final model of academic information ecologies is explained, and a new interactive model of the academic library is presented.

Practical implications: We suggest the implications for the development of information science and for the education of information professionals.

Originality/Value: Original models emphasize values of academic research, values of information, value-added services of academic libraries, and value-sensitive design of digital libraries.
\end{abstract}

\section{Keywords}

Academic libraries. Information behavior of researchers. Information environment. Information infrastructure. Open science.

Received: 31 May 2019. Reviewed: 8 June 2019. Revised: 13 July 2019. Accepted: 18 July 2019.

\section{Introduction}

Information infrastructures are a part of information environment. The term "information infrastructure" refers to digital technologies, values, services, libraries, information professionals and users. New models of scholarly communication emerge with the development of information infrastructures. Digital revolution changes our information behavior in relation to science, education, health and workplaces. Following the trends of digital technologies, new questions emerge regarding information support of scholarly communication. That is why we ask the questions: Which values of information work are valid in digital environment? How should we re-design models of scholarly communication? What information 
support is needed for open science and digital science? What changes should be reflected in new models of academic libraries?

In this paper we focus on the issues related to digital revolution, information infrastructures, open science, information environment and information behavior of researchers. We will briefly analyze related studies of information behavior of researchers and of open science. In the next section, we will discuss the results of three qualitative studies of doctoral students, information managers and researchers which we conducted in Slovakia.

We present characteristics of relevance in the digital environment and a model of information ecology in the academic information environment. Results of the study of information behavior of researchers are visualized on concept maps which represent the researchers' responses to the survey. The selected concept maps present the perceptions of open science, economic models of science and values of research. The analysis of collected data serves us as a basis for a further consideration of the values of information as a resource, as understanding and knowledge, as relevance and as a product. Based on the latest study of the information environment and information behavior of researchers we propose a model of academic information ecologies and a model of an academic library. The framework of information ecologies helps us understand digital information infrastructures, develop a theory of information science and educate new information professionals.

\section{Conceptual background and related studies}

Information environment can be regarded as a complex system of information interactions which support the information process, namely the information lifecycle of creation, processing, communication and use of information (Steinerová, 2018a; Roos et al., 2008). It forms a framework of information processing and use. The related concept of information use environments (IUE) was introduced by Taylor and later re-conceptualized by Byström, Heinström and Ruthven (2019) in relation to the digital information. The phrase "digital environment" designates information interactions mediated by digital tools, digital resources and advanced information technologies in scholarly communication and information use. The increased prominence of the digital environment validates the concept of digital revolution and opens new avenues for the research on digital information (Floridi, 2014).

The information infrastructure consists of networks of people, objects, integrated sources, services and institutions, which include values, social interactions and knowledge (Bowker et al., 2015; Borgman, 2015). Information infrastructures enable information use. They can be described as a substrate upon which something else can operate. The concept of the ecology of information infrastructures implies a holistic perspective of interactions and adaptations of systems, tools, values, resources and people. Information infrastructures are connected to people in information practices, and information structures. Information infrastructures are transparent, invisible, fluid and interoperable. They are embedded in social contexts, and characterized by varying links with communities of practice, and spatial and temporal scope. In scholarly communication information infrastructures provide information, resources and services for researchers. Therefore, the library and information services of information institutions might be understood as a part of information infrastructures. 
Digital scholarship can be explained as a transfer of scholarly communication into the digital environment. Open science emerged as a concept based on trends of open access movement and on access to digital resources and digital publishing, which changed scholarly communication and information use. The most important qualities of open science are digital access, transparency (of methodologies or procedures), and participation (in digital spaces). The emphasis on these qualities has made a significant impact on new models of scholarly communication and information services of academic libraries, and on work of information professionals.

At the conceptual level we will refer to the human information behavior (HIB) as an indicator of information needs of scholars, values of information and patterns of information use. Awareness of HIB can promote the designing of value-added information services, systems and products for researchers.

Human information behavior might be defined as a multilevel human activity related to information use. It is marked by relationships of people to sources and channels of information, and therefore it describes the different ways in which people need, manage, seek and use information (Fisher et al., 2005). HIB is composed of information-related needs, information behavior (searching, browsing, monitoring, seeking) and information use (effects of information) (Ford, 2015). Information practices are understood as a set of socially and culturally established ways to identify, seek, use and share information (Savolainen, 2008). HIB encompasses not only active information seeking, but also unintentional or passive behavior (Case \& Given, 2016).

Empirical studies of information behavior of researchers found that scholars are gatekeepers who share information formally and informally. Many models of information behavior of scientists have been developed. One of the most influential models was developed by Ellis (2005) who identified the stages of information behavior of scholars, including starting, chaining, browsing, differentiating, monitoring, extracting, verifying, and ending. Another non-linear model of information behavior of scholars described the processes of opening, orientation, and consolidation, taking into account cognitive and external factors (Foster, 2004). Differences across various academic disciplines and modes of communication shape different patterns of information use (Talja, 2005; Brown, 2010; Fry, 2013). Recent studies point to new patterns of information behavior of researchers in digital environment, e.g. use of digital resources, data sharing, research data management (Tenopir et al., 2015) and use of social networks (Greifeneder et al., 2018). Xiang (2015) studied open science factors and found gaps in the use of open access sources. Harley et al. (2007) conducted interviews to study academic values which influence publishing, emphasizing the peer review process and weaker interest in electronic publishing. The authors proposed a deeper examination of scholars' needs and encouraged consideration of in-progress scholarly communication. Further studies presented limited use of social media (Bulger et al., 2011) and barriers between information needs of humanities scholars and information infrastructures (McGuiness, 2006). Based on interviews with 22 scholars, Scanlon (2014) found pragmatic patterns of information practices. The pragmatic approach emphasized the visibility and citations in the digital environment. Overall, the scholarship on information behavior of researchers shows that a scholar's discipline shapes his or her use of digital tools. For scholars of different disciplines to collaborate, common ground, readiness, management, planning and translations among disciplines are required (Given 
\& Willson, 2015; Olson \& Olson, 2016; Palmer \& Neumann, 2002). The awareness of these requirements gave rise to the concept of digital scholarship and big data in science emerged (Borgman, 2015; MacKenzie \& Martin, 2016).

\section{Open science and research information interactions}

Open science might be defined as a relation of science to the public, while using of open access sources and tools, digital services, electronic resources and tools. Such an understanding of science is characterized by transparent scholarly communication in society and provision of access to results (Watson, 2015). Its main component is the digital environment which includes open data, open access, open methods and processes, open software, open review and open education. Digital science refers to the transfer of the research process into the digital environment, which includes new digital infrastructures, such as digital libraries, digital tools and services. Open science develops transparent information strategies, methods, and procedures with the emphasis on open access to publications and data. Several models of open science have been developed (e.g. Zuccala, 2009; Lyon, 2016; Open Science Framework, 2014), highlighting open access, transparency, participation, relations with public and promotion. Scholarly communication has been modelled by a number of authors (e.g. Björk, 2005; Hurd, 2000; Whitworth \& Friedman, 2009). These models focused on rich research information interactions in digital environment and new actors (e.g. database providers, web services, digital libraries, aggregators, web editors). Research information interactions can be understood as multilayer relationships of researchers with the information environment. They are shaped by common factors determining information use of researchers, namely methodological background, domain expertise and open science factors (access, publicity) (Steinerová, 2016).

New value-added services for science are designed including sustainable digital information services (Chowdhury, 2014) and management of big research data (Borgman, 2015). For example, Open Science Framework (Centre for Open Science, 2015) have developed guidelines for support of open science, regarding citations, transparency of data, scientific documents, transparency of methods, design and analyses, registration of studies, plans, analyses, and replications of studies. Information professionals keep seeking new economic models of publishing and scholarly communication policies (Open Science, 2017).

One of the most important dimensions of open science is information infrastructure, composed of data and publications. There are many other complementary dimensions of open science, such as social, legislative, and technological aspects, summarized in several European initiatives. The open science models identified transparency, participation, communication, cooperation, and collaboration as contributing factors. Big research data management, electronic journals, digital tools and digital libraries, digital repositories, and social networks also shape the public's relation to science. Digital environment has changed the management of the research process. It gave rise to a need for new models of research assessment and need for new models of information and research ethics. 


\section{Qualitative studies of information behavior in the academic environment: a case of Slovakia}

Our studies of information behavior of doctoral students, information managers and researchers demonstrate the effects of digital revolution and the challenges it poses to information infrastructures. Since 2005 we have run several qualitative studies of HIB with the use of phenomenography. All studies were conducted within the academic information environment as a part of larger projects on information use, information ecology and modelling of the information environment. We used methodologies of semi-structured interviews, qualitative analyses and an original methodology of concept mapping (Steinerová, 2018a). We also participated in an international study of research data literacy and data management (Steinerová \& Ondrišová, 2018).

The first study focused on relevance assessment by doctoral students (2005-2007) (Steinerová et al., 2007). We conducted semi-structured interviews with $21 \mathrm{PhD}$ students and a focus group discussion. Based on multiple qualitative analyses we represented results by many semantic models and several concept maps (perceptions of relevance, types of relevance, relevance in the electronic environment) (Steinerová, 2008; Steinerová, 2011). We re-defined relevance in the digital environment as socio-cognitive relationships supported by interactions, dynamics, construction of meaning. Several types of relevance were identified (10 faces of relevance) and we presented a final model of the collective discourse of relevance. Relevance of information was understood as importance, utility and value. In digital environment we explained three metaphoric faces of relevance as a construction, a pathway, and a pattern. In the digital environment the model of relevance 2.0 was marked by interactivity, dependence on contexts, participation, linking, multi-criterial access, mosaic-like construction of meaning, and non-linearity (Steinerová, 2011).

The second example comes from a study of the information ecology in the academic information environment based on semi-structured interviews with 17 information managers from Slovak universities (Steinerová et al., 2012). The project was realized in 2010-2011. Based on qualitative analyses, semantic representations and further experimental methods we developed a model of the information ecology in the academic information environment. The model showed three dimensions of the information ecology, namely the semantic, the behavioral and the visual dimension. The results had implications for academic libraries and universities, as well as for building digital spaces, digital libraries and repositories. The discourse favoured people, common values, creativity, communication and information sources and digital technologies as the main components of the information ecology. We also identified ecological dimensions of information literacy (Steinerová, 2010), ecological characteristics of digital libraries and information (Steinerová, 2014), information support of research information interactions and methodological literacy of doctoral students (Steinerová \& Hrčková, 2014; Steinerová, 2013).

The third example comes from our latest project focused on modelling of digital scholarship (2015-2017). We conducted semi-structured interviews with 19 expert researchers, applied qualitative analyses and conceptual mapping. We developed 23 concept maps and final semantic models which identified common research information interactions and differences among disciplines (Steinerová, 2018b). The results were published in a monograph on information environment and scholarly communication (Steinerová, 2018a). 
A part of the study was devoted to the attitudes of researchers to open science and digital publishing, economic models of science, and values of research. In the final chapters we proposed a model of academic information ecologies and an interactive model of the academic library.

\section{Examples of concept maps}

With regard to open access, open science and digital publishing, we asked researchers the questions: Do you know the principles of OA sources, open science, do you use OA journals in your disciplines (electronic journals, data archives)? The discourse, composed of all answers, was divided into the elements of support and the critique. In the supportive discourse benefits of open science were identified, such as increase of citations, speed of publishing, promotion of results to broader public, participation, transparency, open access, collaboration, peer networking, information sharing. Researches in STEM fields emphasized advanced technologies, while humanities scholars noted their need for building digital libraries and systems for cultural heritage (e.g. archival memory system of memorable sites, PamMap, atlas of Slavic languages, archaeological digital collections, Maya culture digital sources). In the critical discourse researchers expressed concerns regarding commercial influences and assessment of digital publications. The discourse of perceptions of open access and digital publishing is visualized in the concept map (Fig. 1).

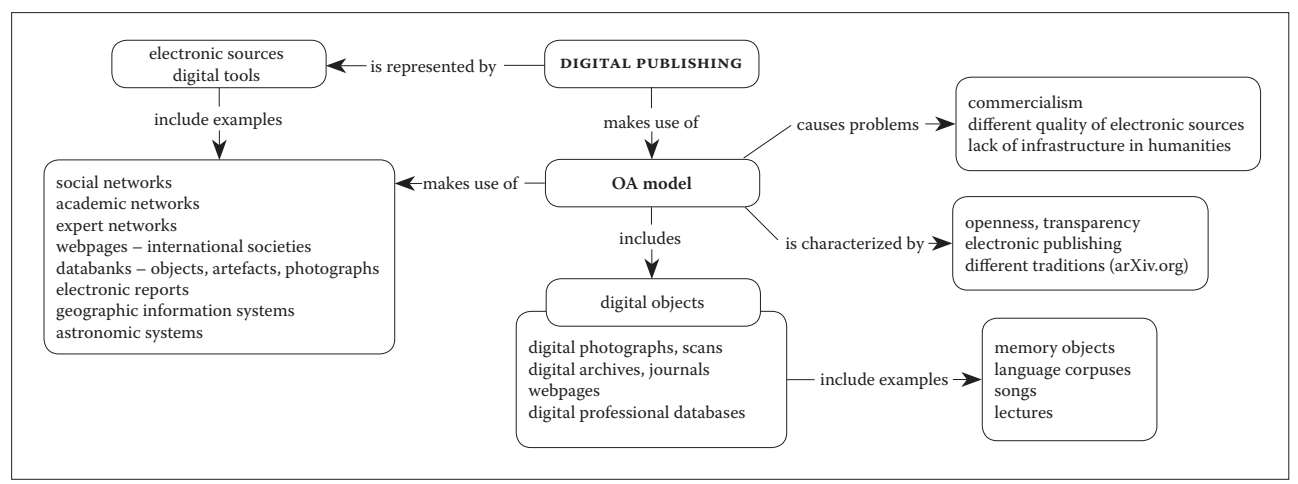

Fig. 1. Perceptions of digital publishing and the OA model (Steinerová, 2018a)

Researchers also strongly praised information policies, access to data and evaluation of results. Less important factors included social media used by researchers, information sharing and alternative metrics. Some scholars expressed agreement with the European trends and policies (Open Science, 2017), whereas others were concerned with lower quality of digital publishing. Several gaps in awareness and use of open access resources were identified. One respondent said:

It is too early for a final conclusion, experiences are mixed. OA brought the invasion of journals...it is visible in the offer...speed of publishing ... (R6). 
Researchers were particularly concerned with the excessive emphasis on quantity with the inappropriate evaluation of publications, and with the position of small disciplines and small countries. Benefits of OA sources were interpreted in context of interdisciplinary cooperation.

OA has also a philosophical, conceptual problem, it is not only finances.... From public sources we support the private companies...I support the green model of OA in order to get rid of the commercial barriers (R5).

The respondents also discussed relations with public and information and research policies.

Another set of questions focused on the perception of the economic models of scholarly communication and open science: What do you think about economic models of scholarly communication in your discipline (paid services versus OA movement, open scholarly communication versus publishing and information industry)? What is your opinion on the open science? The discourse of researchers was mainly critical, but also constructive. Researchers used metaphors of academic market and academic culture in order to describe the co-existence of different models of scholarly communication. Some differences among policies of grant agencies, basic and applied research were considered. The volume of finances for science and research was deemed to be very low:

We need finances for that infrastructure (R19).

Other respondents accepted some competition among projects and relationships with industry:

...we need to sell ourselves and persuade, I find it right and natural (R18).

Some participants recommended combined models of commercial and non-commercial scholarly communication. With regard to open science, researchers pointed to its conceptual problem in mixing the private and public sources and its elimination of differences among disciplines. Perceptions of OA sources and publishing were ambivalent, as concerns were expressed with regard to payments for publishing and predatory journals. Peer review process is regarded as the best way for the assessment of quality of publications. The open space of fast and commercial publishing can represent a threat to academic values. New partnerships with industry can be beneficial for interdisciplinary subjects. Some respondents emphasized the importance of freedom and independence of research. Generally, researchers agreed that academic information culture is a complex system with rich research information interactions and relationships among research, education, industry and publishing. The discourse of the economic models of science and open science is represented on Figure 2.

With regard to values of research we asked the question: Which values are the most important for research work for you in your discipline? The discourse of researchers was divided into the individual values and the social, collective values, while the most appreciated value was contribution to knowledge. The individual values were based on characteristics of the creative personality of a researcher, his or her motivation, interest, curiosity, aspiration to discovery of new perspectives and intellectual accomplishment: 
The social values mentioned by the respondents were the advancement of knowledge, helping people, basic understanding of life, discovery of culture, service to society, and education of young scholars:

The possibility to be ahead in knowledge and to invent something which has not been invented by anyone else before... (R16).

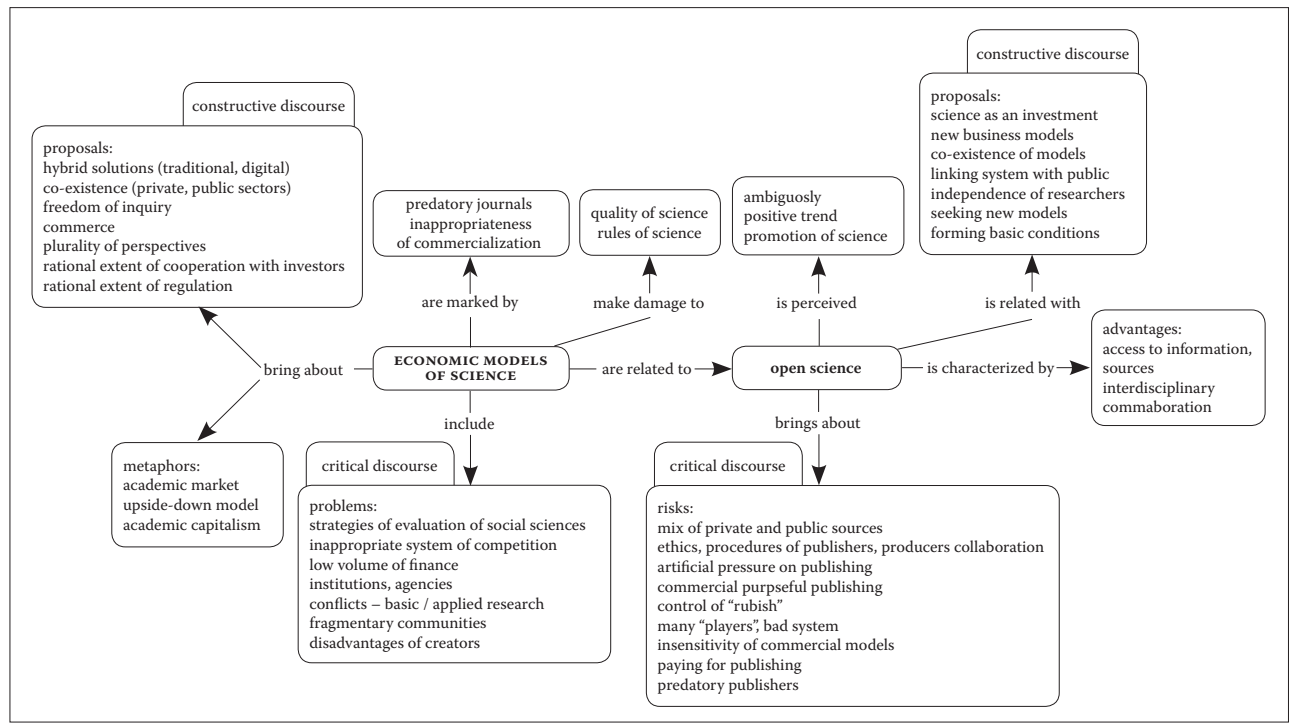

Fig. 2. Economic models of science and open science (Steinerová, 2018a)

The value of research is related to the position of science in society. Our respondents confirmed that there is some contrast between academic and commercial values. The analysis of the discourse is illustrated by the concept map on the Figure 3.

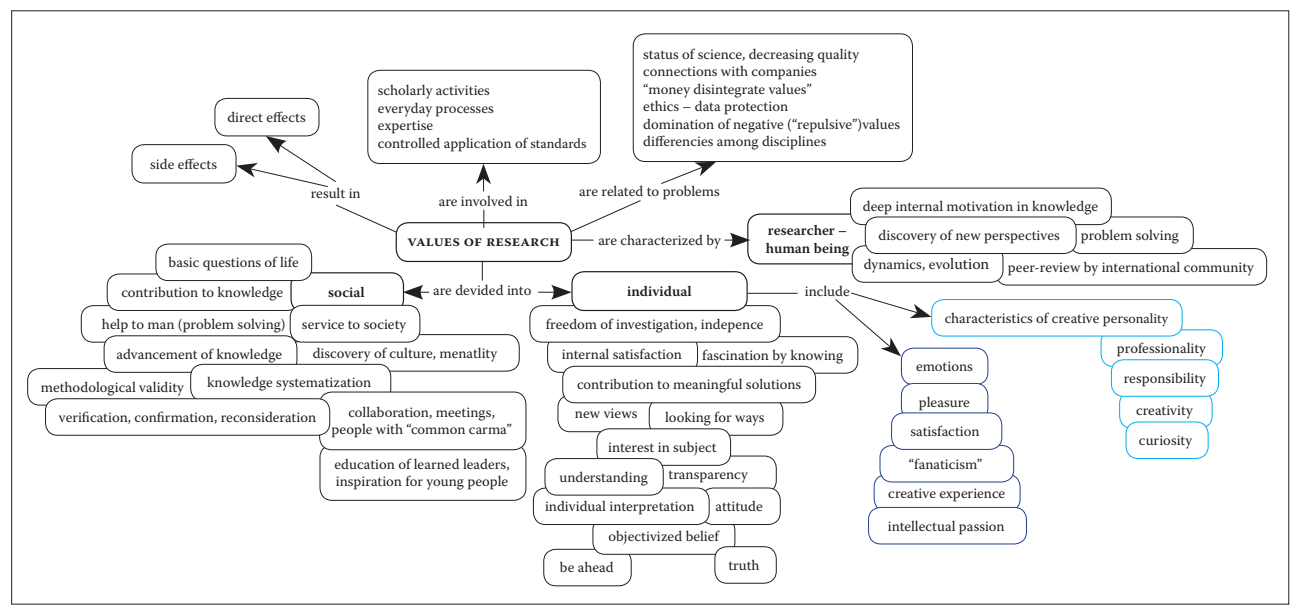

Fig. 3. Values of research (Steinerová, 2018a) 
In further analyses we found that researchers were critical of the system of assessing the research results. Many of them called for reliance on basic academic values preserved in traditions of communication in academic communities:

...simply that value...also with the people with whom I collaborate, they are doing it for that value which it really has, not for that inappropriate counting in our system... (R18).

We found that the perceived value of information depends on the more general value attributed to research. Value of information might also be interpreted as worth, utility and desirability (Norton, 2010). Furthermore, values of information are integrated in the identity of information resources, relevance, information products, understanding and knowledge, and in information as social power.

The three concept maps represent the discourse based on the interviews with researchers. The results demonstrate the complexity of the information environment of scholarly communication and the need for further research on values attributed to information. The interpretation of values, and their transformation in the digital environment should be studied further. We need to explore the issues of building trust, truth, verification of resources, and freedom of expression in order to develop value-added services of academic libraries (Kelly \& Bielby, 2016; Floridi, 2014).

\section{A model of academic information ecologies}

Based on our analyses and on the studies of information ecology, relevance and information behavior we developed a model of the academic information ecologies. It is a framework for understanding the information environment (Fig. 4).

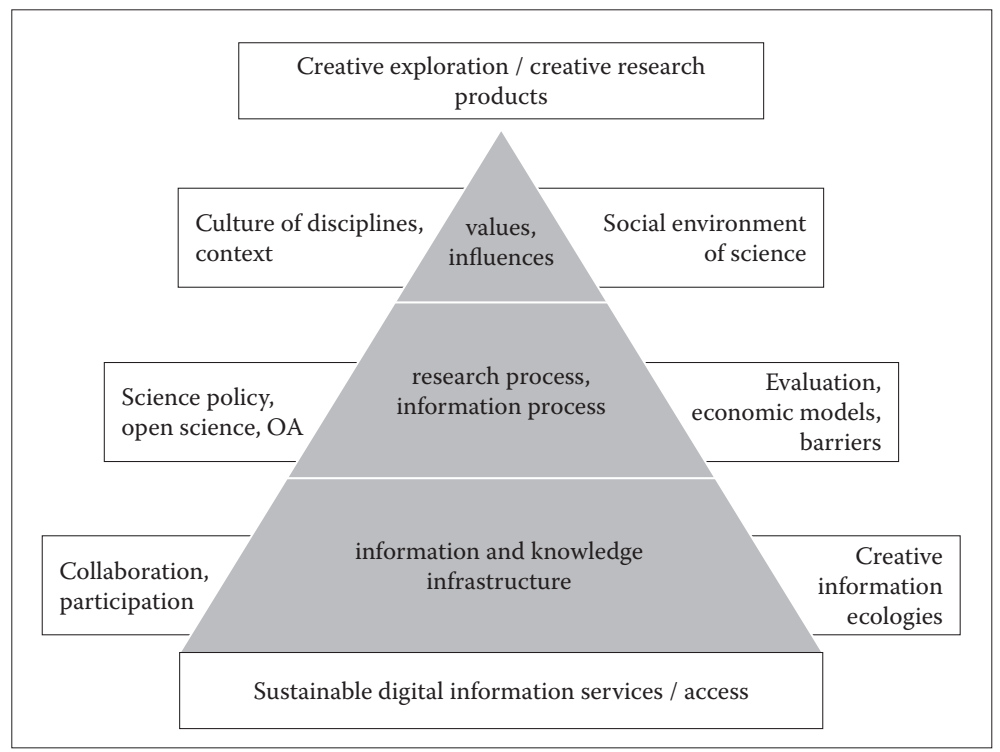

Fig. 4. A mode of academic information ecologies (Steinerová, 2018a) 
This model illustrates the basic infrastructure of digital information access and the following strata of the research process, values and influences of academic cultures and social environment. The model is aimed at a better understanding of the information environment as it emphasizes ecological features of adaptations, interactions, socio-technological evolution and information re-use. Information ecologies are complex information spaces, places, interactions. The model can be applied to information and research policies and further research of values of information and creative exploration. It can also be used for design of value-added services of academic libraries.

\section{An interactive model of the academic library}

Following the results of our studies we designed a model of an interactive academic library. We used proposals of the constructive discourse of researchers with regard to the improvement of library services and information infrastructure. The model is depicted on the Figure 5.

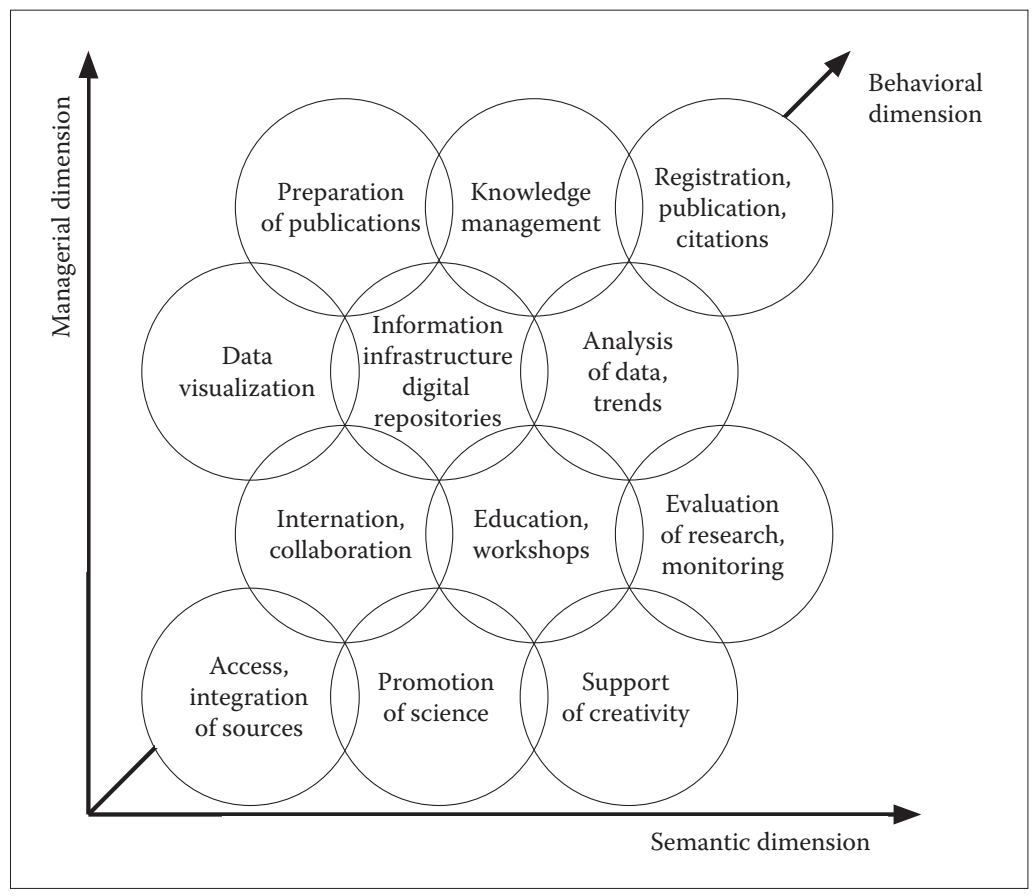

Fig. 5 An interactive model of the academic library (Steinerová, 2018a)

The model is designed as an interactive space based on interactions and dialogue of academic communities. The space is composed of the semantic dimension, the managerial dimension and the behavioral dimension. The inner intertwined circles represent the required value-added services in the three dimensions. In the model we can discover several pathways of transformation of data to knowledge, new ways of information interactions, 
the shift from access to interactive and collaborative information behavior and support of research creativity in digital spaces. This model can help build digital services for academic communities, which would facilitate social networking, open science, project management, publishing strategies and digital ethics. Its features might include interactive digital repositories, research data management and multiple uses of data and information. The perceived value of information and information ethics should be taken into consideration when developing integrative value-added services of academic libraries. The model includes researchers' concerns regarding the issues of data protection, privacy, and intellectual property. The academic library should play a crucial role in scholarly collaboration, networking and innovative teams. Researchers are also interested in support of research data management and digital publishing. Value-added services and value-sensitive design of digital libraries and spaces for researchers should start with an awareness of values of research and values of information for researchers.

\section{Conclusions}

We have reviewed challenges of information infrastructures for open science and academic libraries based on examples of our studies of relevance, information ecology and information behavior of researchers, doctoral students and information managers. Related studies presented the challenges posed by digital environment to development of new, value-added services of information infrastructures and academic libraries. We proposed a theoretical and methodological framework of academic information ecologies and a new model of an interactive academic library.

Information ecology can be regarded as a common background of our models and studies. We emphasize adaptations to changes of the information environment, sociotechnological evolution, re-use of digital information and value-added services focused on creativity, interactivity, social media, information literacy and information ethics. In the digital environment, researchers and information science should pay more attention to concepts of digital literacy and digital ethics. The role of information science will be crucial for understanding the changing digital information environment, as well as risks of digital information and changing services of information infrastructures.

Information science should respond to the challenges of information infrastructures and digital revolution with an enhanced theoretical understanding of scholars' changing pathways in the digital environment and with proposals of new value-added services. Therefore, information research should emphasize values of information and values of research. Emergent services require that new information professionals (e.g. digital librarians and data curators) should be educated in and focused on digital library services, research data management, digital publishing and data curation. Gaps in information infrastructures need to be filled with funded projects and value-added information services supporting scholarly communication in digital environment.

\section{Acknowledgements}

This paper was developed as part of the research project APVV 15-0508 HIBER. 


\section{References}

Björk, B. Ch. (2005). A Life-Cycle Model of the Scientific Communication Process. Learned Publishing, 18 (3), 165-176.

Borgman, Ch. L. (2015). Big Data, Little Data, No Data. Scholarship in the Networked World. Cambridge: MIT Press.

Byström, K., Heinström, J., Ruthven, I., eds. (2019). Information at Work. Information Management in the Workplace. London: Facet.

Bourg, C., Coleman, R., Erway, R. (2009). Support for the Research Process: An Academic Library Manifesto. Report produced by OCLC Research [online]. OCLC Research [15.07.2019], www. oclc.org/research/publications/library/2009/2009-07.pdf

Bowker, G., Timmermans, S., Clarke, A.E., Balka, E., eds. (2015). Boundary Objects and Beyond. Working with Leigh Star. Cambridge, MA: MIT Press.

Brown, C. (2010). Communication in the Sciences. Annual Review of Information Science and Technology, 44, 287-316.

Bulger, M. E., Meyer, E. T., De la Flor, G., Terras, M., Wyatt, S., Jirotka, M., Eccles, K., Madsen, C. (2011). Reinventing Research? Information Practices in the Humanities. A Research Information Network Report, April 2011 [online]. SSRN. DOI: http://dx.doi.org/10.2139/ssrn.1859267

Case, D.O., Given, L. (2016). Looking for Information: A Survey of Research on Information Seeking, Needs and Behavior (4th ed.). Bingley, UK: Emerald.

Center for Open Science. (2016). [online]. Open Science Framework [15.07.2019], https://cos.io/ our-products/open-science-framework/

Chowdhury, G. G. (2014). Sustainability of Scholarly Information. London: Facet.

Ellis, D. (2005). Ellis's Model of Information-Seeking Behavior. In: K. E. Fisher, S. Erdelez, L. McKechnie (eds.). Theories of information behavior (138-142). Medford: Information Today.

Erdelez, S., Means, T. (2005). Measuring Changes in Information Sharing among Life Science Researchers. In: S. Al-Hawamdeh (ed.). Knowledge Management: Nurturing Culture, Innovation and Technology (29-40). New Jersey: World Scientific.

Edwards, P. N., Jackson, S. J., Bowker, G. C., Knobel, C. (2007). Understanding Infrastructure: Dynamics, Tensions and Design. Report of a Workshop on History and Theory of Infrastructure: Lessons for New Scientific Cyberinfrastructures [online]. Washington: NSF [09.08.2008], http://deepblue. lib.umich.edu/bitstream/2027.42/49353/3/UnderstandingInfrastructure2007.pdf

Fidel, R. (2012). Human Information Interaction: An Ecological Approach to Information Behavior. Cambridge, Mass: MIT Press.

Fisher, K.E., Erdelez, S., McKechnie, L., eds. (2005). Theories of Information Behavior. Medford, MA: Information Today.

Floridi, L. (2014). The Fourth Revolution. How the Infosphere is Reshaping Human Reality. Oxford: Oxford University Press.

Foster, A. (2004). A Nonlinear Model of Information-Seeking Behaviour. Journal of the American Society for Information Science and Technology, 55 (3), 228-237, DOI: https://doi.org/10.1002/asi.10359

Ford, N. (2015). Introduction to Information Behaviour. London: Facet.

Fry, J. (2013). Considerations in Adopting a Disciplinary Analysis of Scholarly Communication and Information Behaviours. In: I. Huvila (ed.). ASIST European Workshop (63-78). Abo: Abo University.

Given L.M., Willson R. (2015). Collaboration, Information Seeking, and Technology Use: A Critical Examination of Humanities Scholars' Research Practices [online]. In: P. Hansen, C. Shah, C.P. Klas (eds.). Collaborative Information Seeking. Computer Supported Cooperative Work (139-164). Cham, Switzerland: Springer. DOI:10.1007/978-3-319-18988-8_8

Greifeneder, E. (2014). Trends in Information Behaviour Research. Information Research [online], 19 (4) [16.07.2019], http://www.informationr.net/ir/19-4/isic/isic13.html 
Greifeneder, E., Pontis, S., Blandford, A., Attalla, H., Neal, D., Schlebbe, K. (2018). Researchers' Attitudes Towards the Use of Social Networking Sites. Journal of Documentation, 74 (1), 119-136. DOI: https://doi.org/10.1108/JD-04-2017-0051

Harley, D., Earl-Novell, S., Arter, J., Lawrence, S., King, C.J. (2007). The Influence of Academic Values on Scholarly Publication and Communication Practices. Journal of Electronic Publishing, 10 (2), DOI: http://dx.doi.org/10.3998/3336451.0010.204

Hurd, J. (2000). The Transformation of Scientific Communication: A Model for 2020. Journal of the American Society for Information Science and Technology, 51 (14), 1279-1283.

Kelly, M., Bielby, J., eds. (2016). Information Cultures in the Digital Age. A Festschrift in Honor of Rafael Capurro. Wiesbaden: Springer VS.

Lyon, E. (2016). Transparency: The Emerging Third Dimension of Open Science and Open Data. LIBER Quarterly, 25 (4), 153-171. DOI: http://doi.org/10.18352/lq.10113

Kirchner, J., Diaz, J., Henry, G., Fliss, S., Culshaw, J., Gendron, H., Cawthorne, J. (2015). The Centre of Excellence Model for Information Services [online]. Washington: CLIR. CLIR [16.07.2019], http:// www.clir.org/pubs/reports/pub163

MacKenzie, A. \& Martin, L., eds. (2016). Developing Digital Scholarship. Emerging Practices in Academic Libraries. London: Facet.

Malpas, C., Proffitt. M. (2017). The Transformation of Academic Library Collecting: A Synthesis of the Harvard Library's Hazen Memorial Symposium [online]. Dublin, OH: OCLC Research. DOI:10.25333/C3J04Z.

McGuiness, C. (2006). What Faculty Think-Exploring the Barriers to Information Literacy Development in Undergraduate Education. Journal of Academic Librarianship, 32 (6), 573-582.

Norton, M. (2010). Introductory Concepts in Information Science. 2nd ed. Medford: Information Today.

Olson, G.M., Olson, J. (2016). Converging on Theory from Four Sides. In: D. Sonnenwald (ed.). Theory Development in the Information Sciences (87-100). Austin: Univ. of Texas.

Open Science Research and Innovation. (2017). European Commission. Open Science Policy Platform. [online]. [16.07.2019], https://ec.europa.eu/research/openscience/index.cfm?pg=open-science-policy-platform

Open Science and Research Initiative. (2014). The Open Science and Research Handbook [online]. [23.03.2017], http://openscience.fi

Palmer, C. L., Teffeau, L.C., Pirmann, C. M. (2009). Scholarly Information Practices in the Online Environment: Themes from the Literature and Implications for Library Service Development [online]. OCLC Research [01.12.2017], http:// www.oclc.org/programs/publications/reports/2009-02.pdf

Palmer, C.L., Neumann, L.K. (2002). The Information Work of Interdisciplinary Humanities Scholars: Exploration and Translation. The Library Quarterly, 72 (1), 85-117. DOI: https://doi. org/10.1086/603337

Roos, A., Kumpulainen, S., Järvelin, K., Hedlund, T. (2008). The Information Environment of Researchers in Molecular Medicine. Information Research [online], 13 (3), paper 353 [17.07.2019], http://InformationR.net/ir/13-3/paper353.html

Researcher Development Framework (2011). [online]. Vitae Researcher Development Framework. Vitae. Realizing the Potential of Researchers. Vitae, Careers Research and Advisory Center. 2019. Research Council UK [17.07.2019], https://www.vitae.ac.uk/vitae-publications/rdf-related/researcher-development-framework-rdf-vitae.pdf/view

Savolainen, R. (2008). Everyday Information Practices. A Social Phenomenological Perspective. Lanham: Scarecrow.

Scanlon, E. (2014). Scholarship in the Digital Age: Open Educational Resources, Publication and Public Engagement. British Journal of Educational Technology, 45(1), 12-23.

Steinerová, J. (2008). Seeking Relevance in the Academic Information Use. Information Research [online], 13 (4), 1-11. [01.12.2017], http://InformationR.net/ir/13-4/paper380.html 
Steinerová, J. (2010). Ecological Dimensions of Information Literacy. Information Research [online], 15 (4) [17.07.2019], http://InformationR.net/ir/15-4/colis719.html

Steinerová, J. (2011). Premeny relevancie v informačnej vede a informačná ekológia. Knihovna: knihovnická revue [online]. Praha: Národní knihovna ČR, 22 (2), 59-70 [17.07.2019], http:// oldknihovna.nkp.cz/knihovna112/11259.htm

Steinerová, J. (2012). Information Ecology - Emerging Framework for Digital Scholarship. LIDA 2012 [online], 12 [17.07.2019], http://ozk.unizd.hr/proceedings/index.php/index/index, http:// ozk.unizd.hr/proceedings/index.php/lida2012/article/view/66/37

Steinerová, J., Ilavská, J., Ondrišová, M., Lichnerová, L., Ondriašová, H., Haršányiová, M., Prágerová, L., eds. (2012). Informačná ekológia akademického informačného prostredia. Záverečná správa $z$ výskumu VEGA 1/0429/10. (Information Ecology of the Academic Information Environment. Final Report). Bratislava: Univerzita Komenského.

Steinerová, J. (2013). Methodological Literacy of Doctoral Students - An Emerging Model. In: S. Kurbanoglu, E. Grassian, D. Mizrachi, R. Catts, S. Špiranec (eds.). Worldwide Commonalities and Challenges in Information Literacy Research and Practice (148-154). Heilderberg: Springer.

Steinerová, J. (2014). Ecological Information Interactions for Digital Scholarship. In: P. Návrat, M. Bieliková, M. Laclavík, J, Paralič, J. Steinerová (eds.). Cognitive Traveling in Digital Space of the Web and Digital Libraries. Interdisciplinary Multi-Partner Project TraDiCe (158-169). Bratislava: STU.

Steinerová, J. (2016). Open Science and the Research Information Literacy Framework. In: S. Kubanoglu et al. (eds). Information Literacy: Key to an Inclusive Society (277-285). Cham: Springer, CCIS 676. DOI:10.1007/978-3-319-52162-6_27

Steinerová, J. (2018a). Informačné prostredie a vedecká komunikácia: informačné ekológie. Bratislava: UK.

Steinerová, J. (2018b). Perceptions of the Information Environment by Researchers: A Qualitative Study. Information Research [online], 23(4), paper isic1812. Proceedings of ISIC, The Information Behaviour Conference, Krakow, Poland, 9-11 October 2018: Part 1 [17.07.2019], http://www. informationr.net/ir/23-4/isic2018/isic1812.html

Steinerová, J.(2018c). Informačné prostredie a vedecká komunikácia: aspekty vedeckej dátovej gramotnosti. ProInFlow [online], 10 (2), [17.07.2019], http://www.phil.muni.cz/journals/index.php/ proinflow/article/view/2018-2-2, https://doi.org/10.5817/ProIn2018-2-2.

Steinerová J. (2019). Vedecká dátová gramotnost': konceptuálne východiská a situácia v SR. In: Knižničná a informačná veda. 28. Zborník FiFUK. Bratislava: UK, (in print).

Steinerová, J., Grešková, M., Šušol, J. (2007). Prieskum relevancie informácii. Výsledky analýz rozhovorov s doktorandmi FiF UK. (Survey of Relevance of Information. Results of Analyses of Interviews with Doctoral Students in Faculty fo Arts). Bratislava: Centrum VTI SR.

Steinerová, J., Grešková, M., Ilavská, J. (2010). Informačné stratégie v elektronickom prostredí. (Information Strategies in the Electronic Environment). Bratislava: Univerzita Komenského v Bratislave.

Steinerová, J., Hrčková, A. (2014). Information Support of Research Information Interactions of PhD. Students in Slovakia. The Grey Journal, 10 (2), 79-85.

Steinerová, J., Ondrišová, M. (2019). Research Data Literacy Perception and Practices in the Information Environment [online]. In: S. Kurbanoglu, S. Špiranec, Y. Ünal, J. Boustany, M.-L. Huotari, E. Grassian, D. Mizrachi, L. Roy (eds.). Information Literacy in Everyday Life. ECIL 2018. 6th European Conference, ECIL 2018. Revised selected papers. Oulu, Sept., 24-27, 2018. Cham: Springer Nature Switzerland AG, CCIS 989. DOI: 10.1007/978-3-030-13472-3_51

Talja, S. (2005). The Domain-Analytic Approach to Scholars' Information Practices. In: K. Fisher, S. Erdelez, L. McKechnie (eds.). Theories of Information Behavior (123-127). Medford: ASIST-Information Today.

Tenopir, C., King, D.W., Christian, L., Volentine, R. (2015). Scholarly Article Seeking, Reading, and Use: A Continuing Evolution from Print to Electronic in the Sciences and Social Sciences, Learned Publishing, 28 (2), 93-105. 
Ünal, Y., Chowdhury, G., Kurbanoğlu, K., Boustany J., Walton G. (2019). Research Data Management and Data Sharing Behaviour of University Researchers. In: Proceedings of ISIC, The Information Behaviour Conference, Krakow, Poland, 9-11 October 2018: Part 2. Information Research [online], 24(1), paper isic1818 [17.07.2019], http://InformationR.net/ir/24-1/isic2018/isic1818.html. WebCite $:$ http://www.webcitation.org/74U6bBMqk)

Watson, M. M. (2015). When Will “Open Science” Become Simply “Science”? Genome Biology [online], 16, 1[17.07.2019], https://genomebiology.biomedcentral.com/articles/10.1186/s13059-015-0669-2

Whitworth, B., Friedman, R. (2009). Reinventing Academic Publishing Online Part II: A Sociotechnical Vision. First Monday [online], 14 (9) [17.07.2019], http://firstmonday.org/ojs/index.php/fm/ article/view/2642, DOI: https://doi.org/10.5210/fm.v14i9.2642

Wilson, T. D. (2016). A General Theory of Human Information Behavior. In: Proceedings of ISIC, the Information Behaviour Conference, Zadar, Croatia, 20-23 September, 2016: Part 1. Information Research [online], 21(4), paper isic1601 [17.07.2019], http://InformationR.net/ir/21-4/isic/ isic1601.html

Wilson, T. D., ed. (2013). Theory in Information Behaviour Research (e-book). Eiconics Ltd.

Xiang, R. (2015). The Quandary Between Communication and Certification. Online Information Review [online], 39 (5), 682-697. DOI: https://doi.org/10.1108/OIR-04-2015-0129

Zuccala, A, A. (2009). The Layperson and Open Access. Annual Review of Information Science and Technology, 43, 359-396.

\title{
Wyzwania dla infrastruktur informacyjnych otwartej nauki i bibliotek akademickich
}

\begin{abstract}
Abstrakt
Cel/Teza: W artykule dokonano przeglądu głównych pojęć dotyczących infrastruktury informacyjnej, środowiska informacyjnego i zachowania informacyjnego badaczy w kontekście rewolucji cyfrowej. Rozważana jest koncepcja otwartej nauki i nowe modele komunikacji naukowej.

Koncepcja/Metody badań: Analizie poddano powiązane ze sobą badania infrastruktury informacyjnej i zachowań informacyjnych naukowców. Przedstawiono wyniki serii badań jakościowych dotyczących zachowań informacyjnych i ekologii informacji w środowisku akademickim na Słowacji. Badania te oparte były na wywiadach z doktorantami, badaczami i menedżerami informacji. Wykorzystano opracowaną wcześniej autorską metodologię mapowania pojęć.

Wyniki i wnioski: Uzyskane wyniki pozwalają ponownie rozważyć ocenę relewancji w środowisku cyfrowym i przedstawić model ekologii informacji w środowisku informacyjnym. Analizowane dane przedstawiono za pomocą map pojęć, które pokazują postawy badaczy wobec otwartej nauki, ekonomicznych modeli nauki i wartości badaczy. Objaśniono utworzony na podstawie badań autorski model akademickiej ekologii informacji i przedstawiono nowy interaktywny model biblioteki akademickiej. Zastosowania praktyczne: Sugerujemy zastosowania dla rozwoju nauki o informacji oraz edukacji specjalistów informacji.

Oryginalność/Wartość poznawcza: Przedstawione autorskie modele podkreślają wartości badań akademickich, wartości informacji, usługi o wartości dodanej w bibliotekach akademickich oraz projektowanie bibliotek cyfrowych uwzględniające wartości.
\end{abstract}

\section{Słowa kluczowe}

Biblioteki akademickie. Infrastruktura informacyjna. Otwarta nauka. Środowisko informacyjne. Zachowania informacyjne badaczy. 
Professor JELA STEINEROVÁ is a professor of Library and Information Science at the Comenius University in Bratislava, Faculty of Arts, and the head of the Department of Library and Information Science. In her research and teaching she focuses on the topics of human information behavior, theory and methodology of information science, relevance, information ecology and information products. She has published in home and foreign journals, presented at international conferences. She is a member of boards of international journals and conference committees and projects (e.g. ECIL, ISIC, CoLIS, ENWI). Shas has published several monographs, chapters in books and papers in journals. Her latest monograph is Information Environment and Scholarly Communication: Information Ecologies (2018). She organizes annual international conferences "Information Interactions" in Bratislava.

Contact to the Author:

jela.steinerova@uniba.sk

Katedra knižničnej a informačnej vedy

Filozoficka fakulta Univerzity Komenskeho v Bratislave

Gondova 2, 81499 Bratislava, Slovakia 